\title{
Recenzja
}

\section{Piotr Benedykt Zientarski, Organizacja wewnętrzna Senatu. Studium prawno-ustrojowe, Wydawnictwo Adam Marszałek, Toruń 2011, ss. 214}

Opracowanie Organizacja wewnętrzna Senatu. Studium prawno-ustrojowe autorstwa senatora Piotra Benedykta Zientarskiego to publikacja, która stanowi próbę kompleksowego przedstawienia wskazanej w tytule problematyki na gruncie obowiązujących regulacji prawnych. Autor,z uwagi na pełnioną funkcję ma możliwość prezentacji poruszanych zagadnień z szerszej perspektywy - z uwzględnieniem obowiązującej praktyki i aspektów politycznych.

Recenzowana publikacja składa się z ośmiu merytorycznych rozdziałów, które poprzedza wstęp, wprowadzający czytelnika w omawianą tematykę. Zwięzłe podsumowanie swoich rozważań autor przedstawił w zakończeniu, które umożliwia czytelnikowi prześledzenie najważniejszych wniosków.

W rozdziale pierwszym autor przedstawił genezę Senatu oraz omówił najważniejsze funkcje, jakie ma do spełnienia izba wyższa parlamentu. Z jednej strony ukazał jej wielowiekową tradycję, a z drugiej zwrócił uwagę na pojawiające się od jakiegoś czasu głosy, które postulują jej likwidację. Kolejno przedstawił udział Senatu w realizacji funkcji ustrojodawczej i ustawodawczej, funkcji kontrolnej oraz kompetencje kreacyjne Senatu. Rozważania teoretyczne autor uzupełnił danymi statystycznymi, które umożliwiają czytelnikowi wyrobienie sobie zdania na temat aktywności Senatu.

Rozdział drugi został w całości poświęcony Marszałkowi Senatu. Autor nie ograniczył się jednak do omówienia kwestii podstawowych, takich jak geneza czy sposób wyboru i odwołania Marszałka. Zauważył, że pozycja Marszałka Senatu, będącego zarówno organem państwa, jak i organem wewnętrznym izby, jest złożona. Autor opisał również pozaparlamentarne kompetencje Marszałka Senatu. W tej części opracowania została również przybliżona czytelnikowi instytucja Marszałka Seniora, który - jak trafnie określił autor - ,jest szczególną i tymczasową formą wykonywania kompetencji marszałkowskich". 
W rozdziale trzecim została omówiona problematyka związana $z$ instytucją Prezydium Sejmu. Poruszane zagadnienia obejmują przede wszystkim genezę, pozycję prawną oraz kompetencje Prezydium.

Rozdział czwarty poświęcony został Konwentowi Seniorów, który mimo iż nie znajduje „oparcia” w przepisach Konstytucji, przyjął się niewątpliwie w polskiej tradycji parlamentarnej. Jak wskazuje autor, de lege lata Konwent ma charakter regulaminowego organu wewnętrznego Senatu i został stworzony jako miejsce służące uzgadnianiu najważniejszych kwestii związanych $\mathrm{z}$ tokiem prac izby.

Kolejno w rozdziale piątym została przedstawiona tematyka komisji senackich. Autor podkreśla ich znaczenie, wskazując, że to właśnie w komisjach wykonywana jest większość prac Senatu. W tym miejscu opracowania Autor objaśnił tryb działania komisji oraz omówił ich skład osobowy, kompetencje, a także wskazał na przedmiot działania poszczególnych komisji senackich.

W rozdziale szóstym zostały ukazane możliwe formy zrzeszania się senatorów. W tym miejscu opracowania znajdują się rozważania poświęcone działaniu klubów i kół senackich, a także zespołów senackich i parlamentarnych.

Rozdział siódmy zatytułowany Kancelaria Senatu opisuje strukturę organizacyjną oraz zadania, których wykonanie ma zapewnić Kancelaria. Autor uwzględnił aktualną strukturę Kancelarii, dzięki czemu czytelnik ma lepszą możliwość zrozumienia, w jaki sposób realizowana jest jej podstawowa funkcja, którą zgodnie z Regulaminem jest zapewnienie sprawnego funkcjonowania Senatu i jego organów oraz udzielanie pomocy senatorom w wykonywaniu przez nich mandatu poselskiego.

Ostatni merytoryczny rozdział publikacji zawiera rozważania dotyczące kadencji Senatu i sposobu jego funkcjonowania. Autor wyjaśnia sposób uregulowania problemu kadencyjności w Polsce, przy czym przedstawia także rozwiązania alternatywne. Objaśniając sposób funkcjonowania Senatu, autor skupił się w szczególności na problemie zwoływania posiedzeń, ustalania porządku obrad oraz zasad dotyczących wykonywania przez senatorów prawa głosu. W tej części zamieszczone zostały ponadto dane statystyczne na temat posiedzeń Senatu w latach 1989-2010. Uwzględniają one liczbę posiedzeń, liczbę dni posiedzeń oraz efektywny czas pracy podany w godzinach. Za ciekawostkę można uznać zamieszczenie w opracowaniu danych wska- 
zujących między innymi na najkrótsze posiedzenie czy najpóźniej zakończone posiedzenie.

W Zakończeniu autor dokonuje podsumowania przeprowadzonej analizy. W tym miejscu odnosi się również do głosów opowiadających się za likwidacją drugiej izby parlamentu. Autor podkreśla, że Senat w każdej kolejnej kadencji jest coraz bardziej aktywny, a jego rola nie ogranicza się wyłącznie do współtworzenia prawa. Przeprowadzona analiza w połączeniu z własnym doświadczeniem umożliwiły autorowi spojrzeć krytycznym okiem na obecną kondycję Senatu oraz dostrzec potrzebę zmian. Z podsumowania wynika jednak, że autor nie ma pewności co do przyszłości drugiej izby parlamentu, która to od 1989 r. podlega ciągłej ewolucji.

W recenzowanej publikacji zwraca uwagę sposób, w jaki omawiane zagadnienia zostały przedstawione. Połączenie wiedzy teoretycznej i bogatego doświadczenia praktyka umożliwiły autorowi przekazanie czytelnikowi prezentowanych informacji w sposób ciekawy i zrozumiały.

Wydaje się, że opracowanie może stanowić idealne wprowadzenie dla osób, którym instytucja Senatu jest zupełnie obca. Natomiast czytelnicy, którzy posiadają już pewną wiedzę teoretyczną, mogą odczuć pewien niedosyt ze względu na ograniczony zakres omawianych zagadnień. Grupa ta może być jednak zainteresowana spojrzeniem, jakie na funkcjonowanie izby wyższej parlamentu ma osoba pozostająca wewnątrz jej struktury. Ponadto, mogą one niewątpliwie poszerzać swoje wiadomości, sięgając do literatury przedmiotu, do której odsyła autor.

Za niekwestionowany sukces autora należy uznać to, że mimo ograniczonych ram opracowania, omówił on kompleksowo zagadnienia związane $z$ funkcjonowaniem drugiej izby parlamentu. Zaletą opracowania jest również to, że mimo eksperckiej wiedzy autor posłużył się językiem, który umożliwi dotarcie do szerokiego kręgu odbiorców.

Lektura ta będzie z pewnością stanowiła wartościowy wkład w dyskusję nad kształtem polskiego parlamentaryzmu. Recenzowana publikacja może być przede wszystkim polecana osobom, które chcą zrozumieć zasady funkcjonowania Senatu oraz wyrobić sobie własne zdanie na temat potrzeby jego dalszego istnienia. Lektura ta może być także cenną pomocą dla wszystkich studentów przygotowujących się do egzaminu z prawa konstytucyjnego.

Małgorzata Buszko

(Szkoła Wyższa Psychologii Społecznej) 